\title{
Préfaces des romans français du XIXè siècle, anthologie présentée et annotée par Jacques Noiray
}

\section{Ida Merello}

\section{(2) OpenEdition}

\section{Journals}

\section{Edizione digitale}

URL: http://journals.openedition.org/studifrancesi/9298

DOI: 10.4000/studifrancesi.9298

ISSN: 2421-5856

\section{Editore}

Rosenberg \& Sellier

\section{Edizione cartacea}

Data di pubblicazione: 1 juin 2008

Paginazione: 213

ISSN: 0039-2944

\section{Notizia bibliografica digitale}

Ida Merello, «Préfaces des romans français du xıx siècle, anthologie présentée et annotée par Jacques Noiray», Studi Francesi [Online], 154 (LII | I) | 2008, online dal 30 novembre 2015, consultato il 07 janvier 2021. URL: http://journals.openedition.org/studifrancesi/9298 ; DOI: https://doi.org/ERREUR PDO dans /localdata/www-bin/Core/Core/Db/Db.class.php L.34 : SQLSTATE[HY000] [2006] MySQL server has gone away

Questo documento è stato generato automaticamente il 7 janvier 2021.

\section{$(\mathbb{\theta} \Theta \Theta$}

Studi Francesi è distribuita con Licenza Creative Commons Attribuzione - Non commerciale - Non opere derivate 4.0 Internazionale. 


\section{Préfaces des romans français $d u X I X^{e ̀}$ siècle, anthologie présentée et annotée par Jacques Noiray}

Ida Merello

\section{NOTIZIA}

Préfaces des romans français $d u$ XIXè siècle, anthologie présentée et annotée par Jacques NOIRAY, Paris, Le livre de poche classique, 2007, pp. 447.

1 L'A. propone una scelta delle più importanti préfaces dei romanzi del xIX secolo, dai primi testi romantici, come Atala, Delphine, Oberman, Adolphe, Cinq-Mars, Armance, a Lucien Leuwen (di cui vengono presentate le tre prefazioni), Volupté, Mlle de Maupin, fino a Thérèse Raquin, La Fortune des Rougon, per concludere con Examens des trois romans idéologiques di Barrès e A rebours di Huysmans.

2 L'ampia introduzione, come le premesse a ogni documento testuale, fortemente innervate dal punto di vista critico, tracciano una sorta di storia del romanzo ottocentesco, rendendo subito il volumetto uno strumento indispensabile per lo studente e lo studioso. 